\title{
Brill's Companion to the Reception of Plato in Antiquity
}

\author{
Edited by
}

Harold Tarrant, Danielle A. Layne, Dirk Baltzly and François Renaud

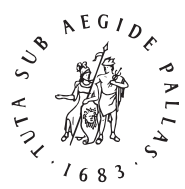

B R I L L

LEIDEN | BOSTON

For use by the Author only | (C) 2018 Koninklijke Brill NV 


\section{Contents}

Acknowledgements IX

Abbreviations $\mathrm{X}$

Notes on Contributors XVI

Introduction 1

\section{PART I}

Early Developments in Reception

Introduction: The Old Academy to Cicero 10

1 Speusippus and Xenocrates on the Pursuit and Ends of Philosophy 29 Phillip Sidney Horky

2 The Influence of the Platonic Dialogues on Stoic Ethics from Zeno to Panaetius of Rhodes 46

Francesca Alesse

3 Plato and the Freedom of the New Academy $5^{8}$

Charles E. Snyder

4 Return to Plato and Transition to Middle Platonism in Cicero 72 François Renaud

PART II

Early Imperial Reception of Plato

Introduction: Early Imperial Reception of Plato 92

5 From Fringe Reading to Core Curriculum: Commentary,

Introduction and Doctrinal Summary 101

Harold Tarrant

6 Philo of Alexandria 115

Sami Yli-Karjanmaa 
7 Plutarch of Chaeronea and the Anonymous Commentator on the Theaetetus 130

Mauro Bonazzi

8 Theon of Smyrna: Re-thinking Platonic Mathematics in Middle Platonism 143

Federico M. Petrucci

9 Cupid's Swan from the Academy (De Plat. 1.1, 183): Apuleius' Reception of Plato 156

Geert Roskam

10 Alcinous' Reception of Plato 171

Carl S. O'Brien

11 Numenius: Portrait of a Platonicus 183

Polymnia Athanassiadi

12 Galen and Middle Platonism: The Case of the Demiurge 206 Julius Rocca

13 Variations of Receptions of Plato during the Second Sophistic 223 Ryan C. Fowler

PART III

Early Christianity and Late Antique Platonism

Introduction: Early Christianity and Late Antique Platonism 252

14 Origen to Evagrius 271

Ilaria Ramelli

15 Sethian Gnostic Appropriations of Plato 292 John D. Turner

16 Plotinus and Platonism 316 Lloyd P. Gerson

17 Porphyry 336

Michael Chase 
18 The Anonymous Commentary on the Parmenides 351

Dennis Clark

19 Iamblichus, the Commentary Tradition, and the Soul 366 John Finamore

20 Amelius and Theodore of Asine 381

Dirk Baltzly

21 Plato's Political Dialogues in the Writings of Julian the Emperor 400 Dominic J. O'Meara

22 Plato's Women Readers 411

Crystal Addey

23 Calcidius 433

Christina Hoenig

24 Augustine's Plato 448

Gerd Van Riel

25 Orthodoxy and Allegory: Syrianus' Metaphysical Hermeneutics 470 Sarah Klitenic Wear

26 Hermias: On Plato's Phaedrus 486

Harold Tarrant and Dirk Baltzly

27 Proclus and the Authority of Plato 498

Jan Opsomer

28 Damascius the Platonic Successor: Socratic Activity and Philosophy in the $6^{\text {th }}$ Century $\mathrm{CE} \quad 515$

Sara Ahbel-Rappe

29 The Anonymous Prolegomena to Platonic Philosophy 533

Danielle A. Layne

$30 \quad$ Olympiodorus of Alexandria 555

Michael Griffin 
31 Simplicius of Cilicia: Plato's Last Interpreter 569 Gary Gabor

Conclusion 580

Bibliography 583

General Index 639

Index Locorum 647 


\title{
Speusippus and Xenocrates on the Pursuit and Ends of Philosophy
}

\author{
Phillip Sidney Horky
}

\section{Introduction}

The educational and institutional structure of the Academy after Plato's death is one of the great unknowns in the history of ancient philosophy. ${ }^{1}$ Harold Cherniss, who thought the answer might lie in the educational curriculum outlined in Republic VII, dubbed it the great "riddle of the early Academy";' contrariwise, in considering the external evidence provided by Plato's students and contemporaries, John Dillon speaks of a "fairly distinctive, though still quite open-ended, intellectual tradition." ${ }^{3}$ One would think, especially given the extent of Plato's discussion of the problem of educational and institutional structures (not to mention the pedagogic journey of the individual teacher and student) that those figures who took over supervision of the Academy after Plato's death - notably his polymath nephew Speusippus of Athens and his popular and brilliant student Xenocrates of Chalcedon ${ }^{4}$ - would have devoted some attention to this issue of educational theory and practice in their writings. After all, several pseudepigraphical texts that are usually considered to have been written in the Academy and were ascribed to Plato - Theages, Alcibiades I (if inauthentic), Alcibiades II, Epinomis, Rival Lovers, On Virtue, the Seventh Letter - do, indeed, devote significant space to elaborating pedagogical methods, practices,

1 Special thanks are owed to Mauro Bonazzi, Giulia De Cesaris, and David Sedley, each of whom read this piece with care and attention. I cannot promise to have responded sufficiently to their challenges in all circumstances, but I can say with confidence that this paper is much improved owing to their critical acumen. Throughout this essay, I refer to Isnardi Parente's (1980) and (2012) editions and translations of Speusippus and Xenocrates with the second edition revised by Dorandi. I often consulted Tarán's edition and commentary of Speusippus as well (1981).

2 Cherniss (1945), 66-72.

3 Dillon (2003), 29.

4 Unfortunately, space does not permit treatment of Polemo or Crates, the scholarchs who followed after Speusippus and Xenocrates. 
and institutional structures, to say nothing of the problem of the possibility of knowledge. ${ }^{5}$ One might go so far as to say that the early reception of Plato involved, at a high level of philosophical engagement, the reception of the theories of education and philosophical knowledge proffered by the great master.

If one were to examine the scholarship concerning those leaders of the Academy after Plato's death, she might conclude that they were almost totally silent on the theory and practice of philosophical education. ${ }^{6}$ It's as if the scholarchs themselves simply weren't engaged in what pretty much everyone in the educational economy of $4^{\text {th }}$ Century Athens was doing. What could explain this strange lacuna in the history of ancient philosophy? It is possible that this is nothing more than an accident of textual survival - there are several works attested for Speusippus and Xenocrates that deal with dialectic and definition, but few fragments of these works survive; or, alternatively, it is possible that the procedures involved in education within the Academy were simply taken over, without alteration, by Speusippus and Xenocrates, and that they simply followed whatever their teacher Plato, as the "architect of the sciences", had told them and practiced with them.

The former hypothesis brings the scholarchs of the Early Academy into fruitful discussion with Aristotle's writings on educational and scientific procedures, especially the Topics, as John Dillon has investigated to fruitful ends; and the latter hypothesis, too, has been used as an explanatory framework not only for the educational programme of the Academy, but also of the Lyceum. Either explanation can justifiably be inferred from the earliest and most important piece of external evidence regarding the philosophical activities of Plato and his students in the Early Academy, an extended fragment of the comedian Epicrates of Ambracia (a rough contemporary of Speusippus):

F 11 Kock = Speusippus F 33 IP

A: What are Plato and Speusippus and Menedemus up to? On what

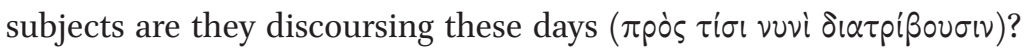

5 I'm not even mentioning the other Socratic dialogues that demonstrate philosophical dialectic, perhaps for the sake of imitation by students. For a useful recent treatment of the Platonic Pseudepigrapha, see Brisson (2014), 11-17; a more penetrating assessment of how the Alcibiades II might represent Platonist work prior to the Sceptical Academy of Arcesilaus, see Tarrant $(2015 \mathrm{~b})$.

6 For example, in his analysis of what philosophical activity looked like in the Early Academy, Berti (2010), 24-29 focuses not on Speusippus, but on Eudoxus and Archytas, neither of whom was a scholarch of the Academy after Plato's death. Similarly, Xenocrates is not discussed in this context. 
What weighty idea, what line of argument is currently being investigated by them? Tell me these things accurately, in Earth's name, if you've come with any real knowledge of it.

B: Why yes, I can tell you about them clearly. For during the Panathenaea I saw a troop of lads in the exercise-grounds of the Academy, and heard arguments indescribable, ridiculous! For, in propounding definitions

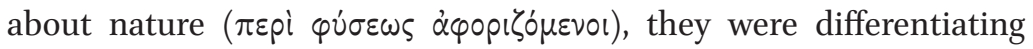

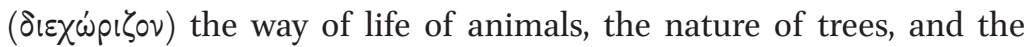
genera of vegetables. And in these arguments, they were investigating to what genus one should assign the pumpkin.

A: And what definition did they arrive at, and of what genus is the plant? Explain it to me, if you really know.

B: Well now, first of all they all took up their places, and with heads bowed they reflected ( $\delta \varepsilon \varphi p o ́ v \tau i \zeta o v)$ a long time. Then suddenly, while they were

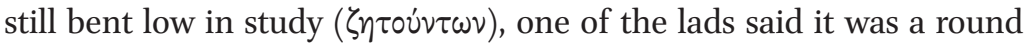
vegetable, another that it was a grass, another that it was a tree. When a doctor from Sicily heard this, he dismissed them contemptuously, as talking rubbish.

A: No doubt they got very angry at that, and protested against such insults? For it is unseemly to behave thus in discussions of this sort.

B: No, in fact the lads didn't seem to mind at all. And Plato, who was present, very mildly, and without irritation, enjoined ( $\left.\dot{\varepsilon} \pi \dot{\varepsilon} \tau \alpha \xi^{\prime}\right)$ them to try again [from the beginning] to define the genus to which the pumpkin belongs. And they started once again to attempt a division (ovńpouv). Dillon (trans.) (2003), 7-8, with alterations.

As Dillon has noted, regardless of any comedic bias, Epicrates' fragment demonstrates a remarkable understanding of philosophical activity and vocabulary. ${ }^{7}$ Indeed, Epicrates' comic portrayal contributes significantly to our knowledge of (at least the contemporary public perception of) the intellectual activities undertaken in Plato's Academy. First of all, it demonstrates a kind of interdisciplinary and international character: the students' study of nature is taxonomic and focuses chiefly on division, but the participants in the discussion include a Sicilian doctor who, it is implied, is not a philosopher of the Academy. The interest in taxonomy reflects similar intellectual excursions by Italians not only in

7 Dillon (2003), 8. In this way, Epicrates follows Aristophanes, whose Clouds lampoons Socratic philosophy by appeal to technical concepts in Presocratic philosophy and Sophistic discourse. See Konstan (2010), 86-87, with bibliography, and Berti (2010), 22-23. 
Plato's Sophist (animals at 221e-222d) and Statesman (animals at 262c-266a), where the Eleatic Stranger holds court, but also Timaeus (animals at 39e; trees and plants at $77 \mathrm{a}-\mathrm{b}$ ), voiced by the eponymous Locrian. Second, there is a specific focus on the patient character of the members of the Academy: neither Plato nor the students react harshly when confronted with the Sicilian doctor's contempt - this surprises speaker A and, it appears, serves the amusement of speaker B, who has characterized the sort of definitions they undertook to be "indescribable, ridiculous" ( $\dot{\alpha} \varphi \dot{\alpha} \tau \omega \nu \dot{\alpha} \tau o ́ \pi \omega \nu)$. Finally, speaker B's narrative emphasizes the authority of Plato over the scene: he makes a point of mentioning that Plato was present, and that the master calmly "enjoined" or "ordered" ( $\dot{\tau} \pi \varepsilon \tau \alpha \xi)$ the students to give the proper diaeresis of the pumpkin a second try.

The possibility of knowledge, and pursuit of it in the natural world, are prevalent themes: notably, the fragment parodies the beginning of several Platonic dialogues, in which one figure seeks to know from another what happened at a particular gathering they attended, first hand, in the past. ${ }^{8}$ Interestingly, this query takes the form of concern over certain knowledge: speaker A asks several times whetherspeakerB really knows (note therepetition of $\varkappa \alpha \tau \varepsilon ı \delta \dot{\omega} \zeta ; x \alpha \dot{\tau} \tau \circ \sigma \theta \alpha \tau \iota)$ what Plato, Speusippus, and Menedemus have been discussing lately. Hence, this epistemic framework playfully informs the actors' curiosity about the Academic discussions involving knowledge and definition of objects in the natural world. Indeed, it is in the midst of differentiating the various Bior of animals and the nature of trees that the subject of defining the pumpkin through differentiae arises. ${ }^{9}$ There is an excellent parallel for this sort of research in Speusippus' Divisions and Hypotheses Regarding Similar Things, a text for which we have a relatively robust set of evidence (Frs 38-47 Isnardi Parente; also note Speusippus proclivity for differentiating substances and principles of things, including animals and plants, in Frs 48-55 and 123-46 Isnardi Parente)..$^{10}$ Indeed, as we will see, Speusippus' approach to division and philosophical dialectic confirms the popular view that we find in Epicrates' comedy of Platonic philosophers

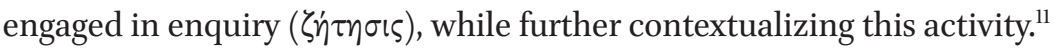

8 Compare with Symp. 172a-174a, Phd. 57a-59d and Parm. 126a-127e.

9 In Rep. Plato had, of course, not only encouraged correct differentiation of the "lives" of the just and unjust men (e. g. $360 \mathrm{e}-363 \mathrm{~d}$ ), but also the various animal "lives" that people took up in the postmortem allotment in the myth of $\operatorname{Er}(617 \mathrm{~d}-620 \mathrm{~d})$.

10 The title is attested at D.L. 4.5 = F 2 IP. It is difficult to know how, or whether, this text differed from other works for which we have titles, e. g. On Typical Genera and Species and Definitions, as noted by Falcon (2000), 410-11.

11 Falcon's (2000), 410 dismissal of the evidence from Epicrates contradicts itself: "Although this testimony is very curious, it can hardly be considered historical evidence about the activity of the members of the Academy. What we can infer from the fragment of Epicrates, 


\section{Speusippus' Mathematikos: The Hunt for Knowledge}

We can infer from several titles of lost works that Speusippus wrote much on the activity and character of the philosopher (On Philosophy, The Philosopher), and on how learning occurs (The Mathematikos, Discussions on Similarities in Science).${ }^{12}$ Although very few testimonia of Speusippus survive that describe his approach to learning, Proclus preserves important information in several passages within his Commentary on the First Book of Euclid's Elements, one of which describes the "hunt" for knowledge:

Proclus, Commentary on the First Book of Euclid's Elements 179.14-22 (Friedlein = Speusippus F 35 Isnardi Parente)

Principles must in every case be superior to what follows after them in simplicity, indemonstrability, and self-evidence. For generally, says

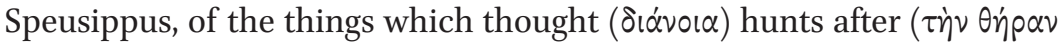
$\pi \circ \varepsilon i \tau \alpha l)$, some it [sc. thought] sets up $(\pi \rho \circ \beta \alpha \lambda \lambda \varepsilon l)$ and prepares for the

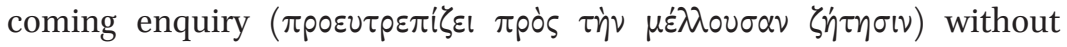
having undertaken any sort of elaborate excursion, and it possesses a

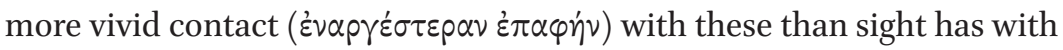
visual objects; others it [sc. thought], because it is unable to grasp them immediately, attempts to hunt after by advancing on them step-by-step according to what follows after these [sc. principles].

Proclus goes on by giving examples from mathematics (179.22-80.22 Friedlein): the former kind of cognition, in which thinking simply apprehends its object, is exemplified by reference to the line that one draws from one point to another. The line is obtained through the "uniform flux" ( $\tau \hat{\eta} \delta \mu \alpha \lambda \hat{\eta} \dot{\rho} \sigma \varepsilon^{\prime}$ ) that attends motion through a point, and hence, so claims Proclus, our thought grasps the line with ease. ${ }^{13}$ The implication is that there cannot be a

I think, is only that the practice of division was important in the Academy." If Epicrates' evidence is taken to show that the practice of division was important in the Academy, how could it not be considered historical evidence about the activity of the members of the Academy? Perhaps Falcon means that it should not be taken as historical evidence for Speusippus in particular; but in that circumstance, he would need to explain why such historical evidence for Speusippus practicing division as is collected by Isnardi Parente exists at all - especially given the fact that so much of Speusippus' work has been lost.

12 See D.L. 4.4-5 = F 2 IP. Nine books are attested for the latter work.

13 On the role of "uniform flux" in the "progression" of mathematical objects, see, inter alia, Cherniss (1944), 396-7 n.322. 
mathematical proof of the line. ${ }^{14}$ By contrast, the construction of a one-turn spiral, which requires construction of multiple geometric shapes and complex motions, cannot be successfully obtained through these simple epistemic operations. The latter activity requires "geometric" thinking. It appears that Speusippus was attempting to describe two functions or activities of "thought" ( $\delta \alpha^{\prime}(v o 1 \alpha)$, based on their objects: simple and indemonstrable mathematical objects such as lines are grasped through apprehension, and they are ontologically and logically prior to their consequents; they are principles of the latter. ${ }^{15}$ Alternatively, complex geometrical objects, which require demonstration and depend upon simple mathematical objects for their construction, are poste-

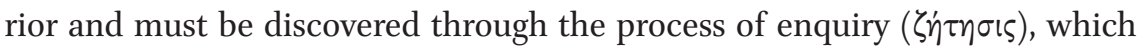
requires multiple steps in the "hunt" for knowledge.

As has been noted, the appeal to the "hunt" for knowledge reflects Speusippus' reception and expansion of ideas found in Plato's dialogues. ${ }^{16}$ In particular, we note that Speusippus bifurcates "thought" ( $\left.\delta i^{\alpha} v o \mid \alpha\right)$, as it is described in the Divided Line passage in Republic vi $(509 \mathrm{~d}-511 \mathrm{e})$, according to simple or complex mathematical objects. ${ }^{17}$ For Plato in the Republic, "thought" is the realm of the sciences and arts, which, according to Glaucon and Socrates, is comprehensible only through use of hypotheses as first principles, and not through exercise of their "intellect" (vôs): we may recall that Glaucon says of the people who study the sciences that they "are forced to observe them through thought, not perception; but on account of the fact that they undertake their examination not by returning to a principle but from hypotheses, they do not seem to you [sc. Socrates] to possess intellect (vov̂v oủx " $\sigma^{\prime} \chi \varepsilon v$ )."18

14 Nothing in the fragment as it is preserved justifies Dillon's claim that "presumably what Speusippus is here asserting is the immediate apprehensibility of the basic principle that a straight line is the shortest distance between two points". Dillon (2003), 84 n.122. There is no propositional content in the testimonium as such.

15 Cf. Bonazzi (2015), 28-30.

16 The "hunt" metaphor refers to dialectical procedures in Plato's dialogues (Phd. 66a; Tht. 198a; Plt. 285d; Sph. 22ob and 261a; Phlb. 65a). Cf. Dillon (2003), 84 n.121. Thanks to Giulia De Cesaris for reminding me of these intertexts.

17 Contra Tarán (1981), 430, who misinterprets by not acknowledging two diverse operations of $\delta \iota^{\prime} v o 1 \alpha$ here based on diverse objects of its attention.

18 Rep. $5^{11 \mathrm{c}} 7^{-\mathrm{d} 2}$. Whether or not Plato would claim that forms qua first principles are intuited, in the sense that scholars often take Aristotle to be eliciting when he speaks of vovs (Analytica Posteriora II.19), is beyond the scope of this paper. Be that as it may, Dillon's (2003), 85, ingenious comparison of the testimony on Speusippus with that passage of Aristotle is slightly misleading, for the simple reason that intuitive principles for Aristotle 
Instead, so Glaucon says, "the state of specialists in geometry and such [sciences] you seem to me to refer to as "thought" and not intellect, since "thought" is something in between opinion and intellect.".19 In Republic VI, it is by no means obvious that when Socrates or Glaucon refer to "first principles", they are speaking about lines, or basic propositions about points relative to one another; they are referring to Forms. If Speusippus continued to retain the Platonic Forms for at least their explanatory function in his bid to, in the words of Dillon, "restructure" and "rationalize" them, ${ }^{20}$ we would need to account for the fact that the Forms were unambiguously the unique first principles that could be grasped by "intellect" (vovs) in the Republic, whereas Speusippus only speaks of grasping first principles in one of the operations of "thought" $(\delta i \alpha \dot{v} \sigma o l \alpha)^{21}$

What Speusippus would have thought of the Platonic notion of the "intellect" (vôs), and its proper objects, is difficult to infer from his surviving fragments. ${ }^{22}$ What is clear from what survives, however, is that Speusippus placed a lot of emphasis on the demonstrative aspect of learning that one employs in enquiry

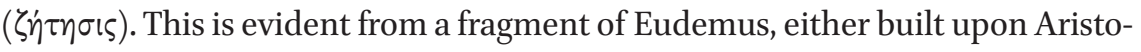
tle's account in the Posterior Analytics (II. 13, 97a6-22 = F 39 Isnardi Parente)

are obtained via voûs, whereas for Speusippus they are obtained through the simpler type

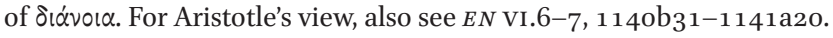

19 Rep. $511 \mathrm{~d}_{3}-5$.

20 Dillon (2003), 49. I do not have space here to discuss Speusippus' rejection of the Forms, as asserted by Aristotle (Metaph. XIII.1, 1076a19-29 = F 74 IP; Metaph.viI.2, 1028b1824 = F 48 IP) and effectively discussed by Berti (2010), 105-10. For further doubts about Dillon's hypothesis, see Bonazzi (2015), 13-14 with n.37.

21 It is worth noting, however, that Socrates in the Palinode $(P h d r .247 \mathrm{c}-\mathrm{d})$ does refer to the gods' observation of true being as involving "thought" ( $\left.\delta \dot{\alpha}^{\prime} v o \alpha\right)$ which is steered by "intel-

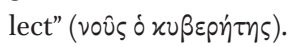

22 An enigmatic doxographical statement by Aëtius (De placitis reliquiae 1.7.20 = F 89 IP) constitutes almost all we know about Speusippus' conceptualization of vov̂, although it is unclear what exactly is being said there. A challenging testimonium by Sextus Empiricus (Adv. Math. 7, 145-6 = F 34 IP), possibly taken over from Antiochus of As-

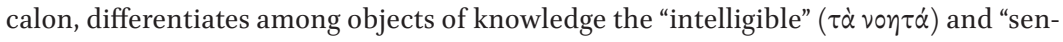

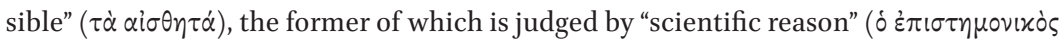

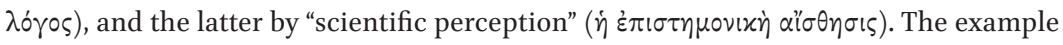
that follows, however, chiefly explains how the latter participates in the former. We might infer from what Sextus says, however, that intelligibles would consist of mathematical properties such as "harmonious" and "non-harmonious". See Bonazzi (2015), 29 with n.83. 
or deriving from Speusippus' own work, ${ }^{23}$ that ascribes to Speusippus the claim that definition of a single definiendum is impossible without knowledge of everything:

Anonymous Commentator on Aristotle's Posterior Analytics 584.1 7-585.2 (Wallies = F 39 Isnardi Parente)

This doctrine is said by Eudemus to be that of Speusippus, that it is impossible to define any of the things that are without knowing all the things that are. And since it seems to bear some plausibility, [Aristotle] posits it. For the argument which he thinks can demonstrate this runs on the following lines: it is necessary for one who defines something to know its difference in relation to all things that are different from it. For, indeed, what doesn't differ in any way from something is the same as it; but what does differ is other. So, it is necessary for one who defines something as differing from other things to know its differentiae, those by which it differs from other things. For if someone doesn't know this, he will believe both that what is the same is other and what is other is the same. In this way, he will not state the essence that is proper to something; for if this should so happen, nothing prevents the definition produced from being common to some other things as well. But it's impossible to know something's difference in relation to certain [other] things without also knowing the things from which the proposed object differs. Therefore, it is necessary for one who defines something to know all things, for the one who defines is defining both this (for how [else] could he define it?) and all the things other than which it is itself defined as being other. ${ }^{24}$

It's difficult to extract from this passage what Speusippus' real project was in describing how one can and cannot obtain definitions of essences, although Eudemus implies that Speusippus preferred to define objects through arguments from identity and similarity over aliorelativity. ${ }^{25}$ Importantly, however,

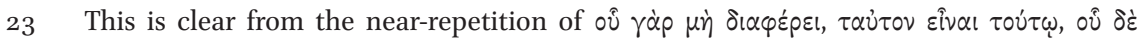

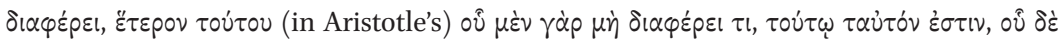

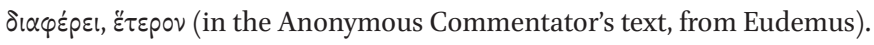

24 Thanks especially to David Sedley for suggestions on translating this challenging passage.

25 For "aliorelatives", I am referring to definitions posited $\pi$ pò trasted from definitions formed $\tau \alpha$ i $\tau 0 v$. Generally, on aliorelatives in Plato's philosophy, see Duncombe (2012). 
Speusippus is not to be credited here with any sort of proto-sceptical argument that a regress implies that no essence can be known whatsoever ${ }^{26}$ rather, the claim could be used in to show that prenatal knowledge of all the essences is required for knowledge of any single essence, which can only, in fact, be obtained via discursive dialectic. ${ }^{27}$ In this way, Speusippus could be seen to extend Plato's commitment to a theory of psychic recollection, as a response to Meno's worries about the possibility of knowledge and its transmission through education (Meno 8oa-82a). Here we may recall Socrates' demonstration in the Phaedo that human beings must not only recollect the essence of the object under scrutiny, but also all the essences that may be considered relevant to it in a relation of similarity or difference $(P h d .72 \mathrm{~d}-76 \mathrm{e}$, especially $75 \mathrm{~b}-76 \mathrm{~b}){ }^{28}$ Or we might recall the image in the Phaedrus $(247 \mathrm{c}-\mathrm{e})$, in which the unmixed soul-chariot sometimes pauses at the edge of the universe and gazes upon the forms of justice, temperance, and knowledge - "the things that really are" ( $\tau \dot{\alpha}$

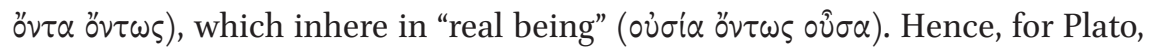
the soul's familiarity with the all the Forms of things is required for successful identification of each of them, and of each of the natural objects that imitate them, when incarnate, i. e. in a state in which essences have been forgotten. ${ }^{29}$ Similarly, Speusippus looks to be adapting Plato's argument by stipulating that the mind must have had knowledge of all essences at some point in the past in order for it to successfully determine any one essence through dichotomous definition. This positive interpretation of the testimonia accounts for the dif-

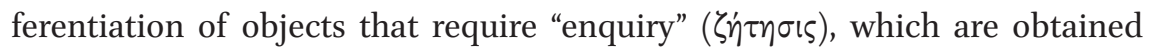
through discursive thinking (and quite possibly interpersonal dialogue), and

26 Cf. Tarán (1981), 390.

27 Cf. Plt. 286a, describing the benefits of obtaining definitions through discussion: "That is why one must practice at being able to give and receive an account of each thing; for the things that are without body, which are finest and greatest, are shown clearly only by verbal means and by nothing else [...]." (trans.) Rowe.

28 This is my understanding of the important passage at Phd. 76a1-4, which Sedley and Long translate: "Right, because this was shown to be possible: upon perceiving something - whether by seeing or hearing, or by some other perception of it - thanks to it, to come to think of something else which one had forgotten, something with which the first thing, though dissimilar, had a connection, or something to which it was similar" (italics mine). See the next note.

29 It is important to qualify this statement: I am not saying that at the moment of perceiving an object, the soul recollects all the essences at once; rather, at that very moment, the soul recollects those essences that are said to "consort" or "associate" with ( $\dot{\varepsilon} \pi \lambda \eta \sigma^{\prime} \alpha \zeta \varepsilon v$ at Phd. $76 \mathrm{a} 3$ ) the object being perceived. 
those objects that are grasped intuitively or, at the very least, more "easily"; it also helps to explain the fact that Speusippus did, indeed, attempt to make taxonomic definitions of various sorts of animals and plants in his fragments (see frr. 123-146 Isnardi Parente). ${ }^{31}$

The evidence discussed above shows that Speusippus was committed to developing theories of definitional dialectic that were focused on proper procedure, which could not proceed solely from aliorelatives if they were to obtain the proper essences of things. While he did reject the separate Forms that had grounded Plato's metaphysics, he nevertheless does not appear to have embraced the scepticism that has sometimes been associated with his epistemology. The evidence suggests that Speusippus' theory of education was focused

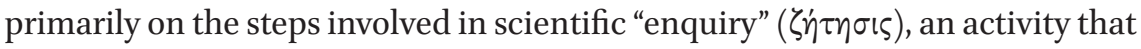
required multiple interlocutors working together in the hunt for knowledge. Hence, Speusippus adapted and extended what Plato had already described in several works, especially those dialogues composed later in life, to suit a project of scientific taxonomy. Despite the postulation of a robust axiomatic metaphysical-mathematical scheme (well-discussed by other scholars), there is no compelling evidence that Speusippus associated this scheme with learning itself; rather, it was preparation for the journey to come.

\section{Xenocrates on the Happy Man}

If Speusippus focused on the correct procedures involved in the (re)discovery of knowledge, his successor to the Academy, Xenocrates, sought to explain why one should seek knowledge at all. Hence, Xenocrates was credited by philosophers and doxographers in the Hellenistic period with explaining the ends of philosophy. It is well known that Xenocrates' philosophy was, from Antiochus forward, strongly associated with Speusippus', but there remained some room for differentiation of their approaches to the unified system of Platonic philosophy. Consider, for example, Varro's account of Platonic philosophy in Cicero's Academica Posteriora:

Cicero, Academica Posteriora 4.17 = Xenocrates T $82 \mathrm{IP}^{2}=$ Speusippus F $25 \mathrm{IP}$ But by the authority of Plato, who was [a thinker] complex, manifold, and productive, a single univocal system of philosophy was founded - with

30 Aristotle, too, refers to pursuit of definitions through division and collection as occurring

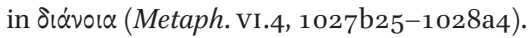


two names, Academics and Peripatetics, which, while agreeing in doctrines, differed in name. For although Plato had left Speusippus, his sister's son, as "heir", as it were, nevertheless two men of outstanding zeal and learning (praestantissimos studio atque doctrina), Xenocrates of Chalcedon and Aristotle of Stagira ${ }^{32}$ those who were with Aristotle were called "Peripatetics", because they conducted debates (disputabant) while walking around inside the Lyceum, but those who, according to the practice of Plato, assembled and customarily held discussions (sermones) in the Academy, which is another exercise-ground, obtained their appellation from the name of the place.

Interestingly, Varro's account presents Speusippus as a mere "heir" to Plato's doctrines, whereas he emphasizes the strong connections between Xenocrates and Aristotle, referring to them as praestantissimi studio atque doctrina. Their superiority with regard to studium and doctrina is emphasized by Varro, and they are juxtaposed with one another, leaving poor Speusippus out on his own. ${ }^{33}$ There are also some implicit differences signalled by the language: philosophical engagement at Aristotle's Lyceum is taken to be more dialectical, with the emphasis on disputation (disputabat), whereas at Xenocrates' Academy it is more relaxed and conversational (sermones). ${ }^{34}$

Furthermore, Varro's emphasis on studium and doctrina is worth remarking on: ${ }^{35}$ the latter, which would in Greek be $\delta \delta \delta \alpha \sigma \kappa \alpha \lambda i \alpha$, indicates their pedagogical commitment to philosophy in its manifold univocality; ${ }^{36}$ the former, however, is in some ways more interesting, since it indicates a deep commitment to the project of philosophy - we may here wish to recall that one of

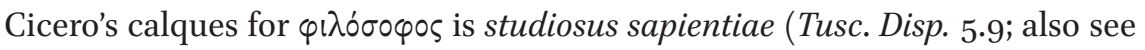
Tusc. Disp. 1.1, on $\varphi(\lambda \circ \sigma \circ \varphi$ i $\alpha$ ), a term that is difficult to translate back into Greek from Latin. It is not a direct transliteration of Greek $\varphi 1 \lambda \circ \sigma \circ \varphi{ }^{\alpha} \alpha$, which

32 The grammar is unclear here, as there is no stated main verb.

33 Contrast, for example, Piso's description of Antiochus' view at De fin. 5.7, in which Aristotle is rendered the princeps over Speusippus, Xenocrates, Polemo, and Crantor as a group (i. e. the peripatetici).

34 Compare Epicrates' description above of the activity in the Academy as "discoursing"

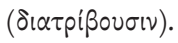

35 The coupling of studium with doctrina in Cicero is not rare, occurring at, e. g. De or. 1.11 and 3.230 (where it appears alongside ingenium and memoria); Brutus 240 (coupled with industria and labor); and De senectute 49 .

36 Blank (2012), 259-6o notes that one important difference between Piso and Varro's positions is that the latter believes that virtue is implanted by instruction (doctrina), whereas the latter assumed that virtue could not be fully achieved without it. 


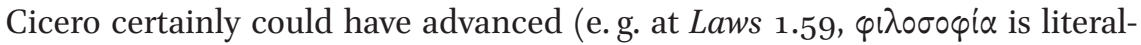
ly rendered as amor sapientiae). ${ }^{37}$ The term studiosus, and its abstract form studium, are more nuanced, implying a kind of commitment to enquiry and scientific dedication that are not indicated by the literal translation of $\varphi i \lambda i \alpha$ into amor. It is difficult to infer a direct Greek cognate in Cicero's own works.

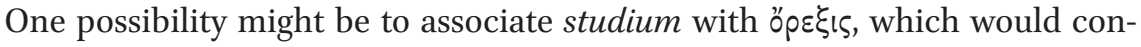

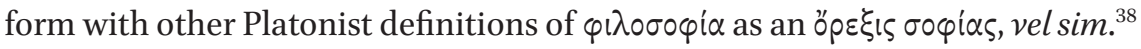
The problem here is that there is no easy cognate that follows for studiosus, ${ }^{39}$ and ${ }^{\prime} \rho \varepsilon \xi ı$ does not do the work of explaining the sustained commitment to wisdom implied by the term studium. Another possibility, this time arising out of the Stoic world, is $\ddot{\alpha} \sigma x \eta \sigma ı \varsigma:$ after all, we have it on the authority of Aëtius

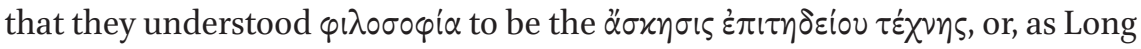
and Sedley translate, "the practice of expertise in utility." ${ }^{40}$ This possibility has the value of retaining the close connections between the Xenocratean and the Stoic division of philosophy into physics, ethics, and logic. ${ }^{41}$ But, again, the Stoic philosopher is not anywhere (to my knowledge) called an $\dot{\alpha} \sigma x \eta$ tò $\tau \hat{\eta} \varsigma$

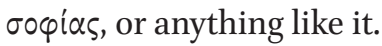

Another possibility that, I think, holds more traction for our understanding of Varro's philosopher as a studiosus who is committed to his studium, is attested in the medieval translation tradition of Aristotle's Topics and Nicomachean Ethics, extending from Boethius to Thomas Aquinas, where we consistently see the terms studiosus and studium used to translate $\sigma \pi 00 \delta \alpha i o \zeta$ and $\sigma \pi 00 \delta \dot{\eta}$, respectively. ${ }^{42}$ For Aristotle, the term $\sigma \pi 0 v \delta \alpha$ ios plays an important role in his definition of human happiness, the supreme good that is indicated by appeal to the function of a human being, in the famous "function argument":

37 My discussion here has benefited from Baraz (2012), 96-112.

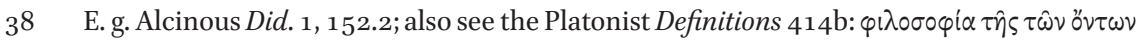

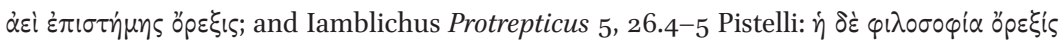

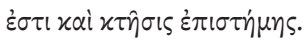

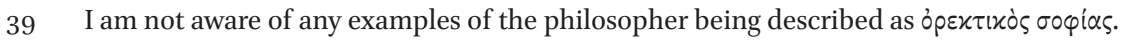

40 Aët. 1, Preface $2=\mathrm{L} \& \mathrm{~S}_{2} 6 \mathrm{~A}=S V F 2.35$.

41 Cf. Dillon (2003), 138-42.

42 Boethius ap. Aristoteles Latinus v.1, 39.23-40.1 Mino-Paluello, translating Aristotle Top. II.6 below; the author of the "ethica nova", often thought to be Burgundio of Pisa, ap. AL XXVI.1, translating Aristotle $E N$ I.7, 78.3-12 Gauthier; William of Moerbeke, following the author of the "ethica nova" in, ap. Aristoteles Latinus XXVI.3, translating EN I.7, 384.4-11 Gauthier; for Thomas Aquinas, see Summa Theologica 1 a1, 6, where the virtuosus is differentiated from the studiosus because the latter requires studium ad doctrinam in order to make judgments, whereas the former grasps principles ex revelatione. 
Aristotle, Nicomachean Ethics I.7, 1098a7-18

If the function of the human being is activity of soul in accordance with reason, or not apart from reason, and the function, we say, of a given sort of practitioner and a serious $(\sigma \pi \circ v \delta \alpha i o \varsigma)^{43}$ practitioner of that sort is generically the same, as for example in the case of a cithara-player and a serious ( $\sigma \pi 00 \delta \alpha i o \varsigma)$ cithara-player, and this is so without qualification in all cases, when a difference in respect of excellence is added to the function (or what belongs to the citharist is to play the cithara,

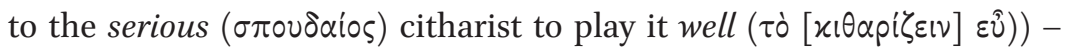
if all this is so, and a human being's function we posit as being a kind of life, and this life as being activity of soul and actions accompanied by reason, and it belongs to a serious man ( $\sigma \pi \circ \cup \delta \alpha \tilde{o} \circ$ ) to perform these

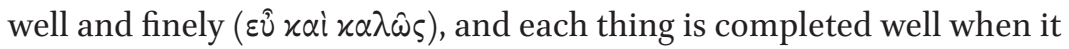

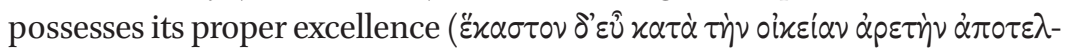
$\varepsilon \tilde{\tau} \alpha \mathrm{l})$ : if all this is so, the human good turns out to be activity of soul in accordance with excellence (and if there are more excellences than one, in accordance with the best and most complete). (trans.) Rowe, with minor alterations

Aristotle has already argued (at 1097b22-1098a7) that the function of the human being is the activity of its soul in accordance with reason; but here he adds that there is an important difference between the function of any human being and the human function that is most complete and best, which is exemplified by the serious ( $\left.\sigma \pi \circ v \delta \alpha i \sigma^{\circ}\right)$ practitioner of any art, i. e. the one who practices his art in accordance with the excellence/virtue that is proper to

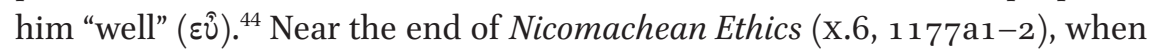
laying the ground for his final description of happiness being the fully contemplative life, Aristotle is more to the point: the happy life is what is in accordance with virtue ( $\left.\varkappa \alpha \tau^{\prime} \dot{\alpha} \rho \varepsilon \tau \eta^{\prime} \nu\right)$, i. e. that which is conducted "with seriousness" ( $\mu \varepsilon \tau \dot{\alpha} \sigma \pi \circ v \delta \hat{\eta} \varsigma)$.

43 I translate $\sigma \pi 0 v \delta \alpha \tilde{o} \varsigma_{5}$ with "serious" rather than "good", although Aristotle does routine-

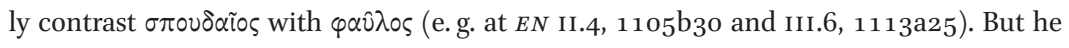
also contrasts it with $\gamma \varepsilon \lambda_{0} \hat{i} \varsigma_{\text {at }} E N$ X.7-8, 1177a2-5, again in the context of discussing the happy life and happiness. Consider Finnis' (1998), 48 description of a studiosus, by reference to its use in Thomas Aquinas: "Studiosus is simply a translation handed to Aquinas for Aristotle's keyword spoudaios, the serious, morally weighty, mature person whose views and conduct deserve to be taken seriously-the right-minded person." 
Interestingly, Aristotle's focus on the virtuous life lived seriously reflects broader eudaimonistic traditions found in the Early Academy: indeed, we are led to believe that Xenocrates advanced similar arguments, as Aristotle himself suggests:

\section{Aristotle, Topics II.6, 112a32-38 = Xenocrates F 154 Isnardi Parente ${ }^{2}$}

Another method of attack is to refer a term back to its root meaning ... Similarly, "happy" ( $\varepsilon \dot{\delta} \delta \alpha i \mu \omega \nu)$ can be used of one whose spirit is serious ( $\delta \delta \alpha i \mu \omega \nu \sigma \pi 0 v \delta \alpha i 0 \varsigma$ ), as Xenocrates says that "he who possesses a soul

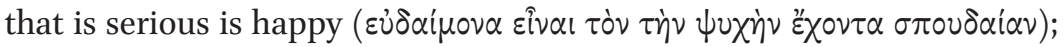
for this [sc. the soul] of each man is a spirit." (trans.) Horky

Later on, Aristotle explains that by referring to the "happy" life as that which is psychologically "serious", Xenocrates was committed to the idea that the "serious" life is that which is "most choiceworthy of all lives", and that what is choiceworthy is the same thing as what is greatest. ${ }^{45}$ Hence, so goes the implication, ${ }^{46}$ the happiest life, which is the most choiceworthy and hence greatest, is the life that is "serious". "Serious" in what sense? Obviously Xenocrates was

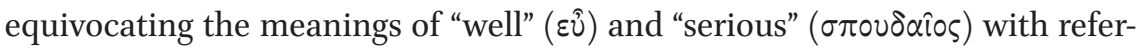
ence to the activities of the soul, which is, or is at least similar to, a daemon. ${ }^{47}$ Perhaps he does this in service of an argument relating the proper end of human life with the practise of virtue. ${ }^{48}$ Unfortunately, beyond this, no other substantive evidence survives, but it would not be unreasonable to assume that

Top. vil.1, 152a 5-30 = Xenocrates F $158 \mathrm{IP}^{2}$.

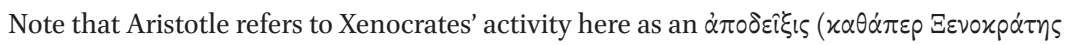

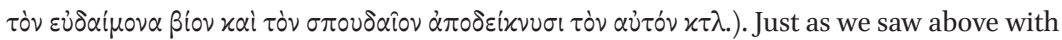
Speusippus, the argument, though obscured by Aristotle's summarizing, is conducted from similars, rather than from aliorelatives.

47 It is interesting to consider Boethius' translation here, which fails to retain the etymol-

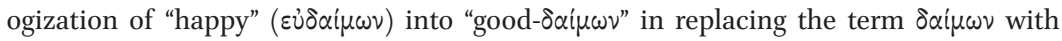
fortuna: similiter autem et bene fortunatam, cuius fuerit fortuna studiosa, quemadmodum Xenocrates dicit bene fortunatum esse qui animam habet studiosam. On soul as $\delta \alpha i \mu \omega \nu$ in Xenocrates, see Dillon (2003), 146-9.

48 This would help to explain Cicero's claim that the happiest life is the one practised in virtute (Tusc. Disp. V.51 = Xenocrates F $161 \mathrm{IP}^{2}$ ), or Clement of Alexandria's claim that "Xenocrates of Chalcedon argued that happiness is the 'possession of proper virtue and

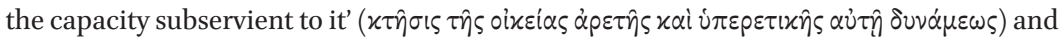
that the 'parts' of the virtues are 'fine deeds and serious dispositions, as well as states, motions, and arrangements"' (Strom. II.22 = Xenocrates F $150 \mathrm{IP}^{2}$ ). 
Aristotle's elaborate theory of the "serious" man, which was fundamental to his celebrated function argument, was actually indebted to, if not based on, arguments advanced by his competitor Xenocrates concerning intellectual seriousness and commitment to philosophical enquiry.

About the ends of philosophical enquiry according to Xenocrates we are better informed: Pseudo-Galen tells us that Xenocrates believed that the "cause of the discovery of philosophy is putting an end to the confusions of

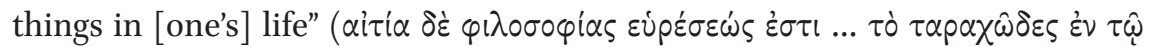
$\left.\beta^{\prime}(\omega) \alpha \alpha \alpha \pi \alpha \hat{v} \sigma \alpha l \tau \hat{\omega} \nu \pi \rho \alpha \gamma \mu \alpha \dot{\alpha} \tau \omega \nu\right) .{ }^{49}$ It is worth comparing this with Speusippus' definition of happiness ( $\left.\varepsilon \dot{\delta} \delta \alpha \mu \rho v^{\prime} \alpha\right)$ as "a habit perfected in reference to what

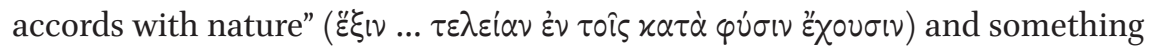

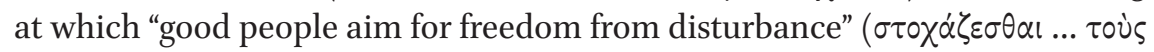
$\left.\dot{\alpha} \gamma \alpha \theta 0 \dot{\jmath} \varsigma \tau \hat{\eta} \varsigma \alpha \alpha \chi \lambda \eta \sigma^{i} \alpha \varsigma\right) .{ }^{50}$ Xenocrates' final cause for the human discovery of philosophy was the arresting of "confusions of things" in life, a phrase whose difficulty to interpret is evident: does Xenocrates reject, as Isnardi Parente takes him to, ${ }^{51}$ Aristotle's famous claim that the origin of philosophy is intel-

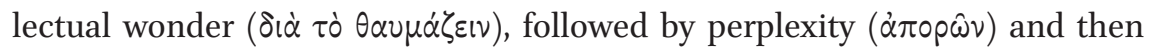

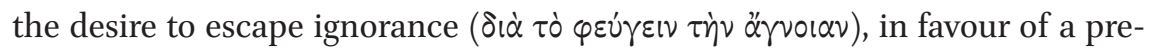
Hellenistic theory of the pacification and removal of disturbed emotions? ${ }^{52}$ I suspect Xenocrates is more ambivalent here, with a phrase that accounts for both the contemplative and the practical lives, both of which are part of

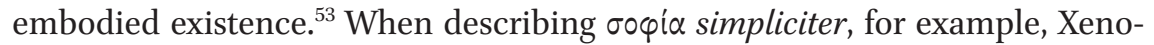
crates referred to the "science of first causes and of the intelligible substance"

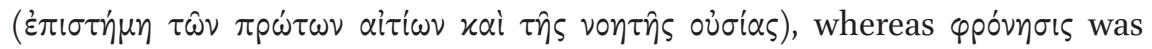

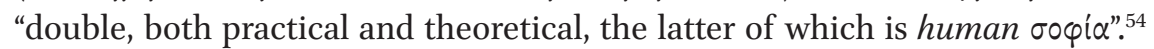
Theoretical knowledge, then, could be applied to human life, just as practical knowledge, and it would involve inquiry into the causes of human (rather than divine) knowledge. The remarkable use of the term $\tau \alpha \rho \alpha \chi \omega \hat{\omega} \varepsilon \varsigma$, , however, also indicates a movement in the direction of developing a technical language for what will become a fundamental problem for Epicurean, Stoic, and Platonist philosophers of the Hellenistic Era.

49 Ps-Galen, Historia philosophica 6, p. 605 Diels = Xenocrates F $171 \mathrm{IP}^{2}$.

$50 \quad$ Clement, Strom. II.22 = Speusippus F 101 IP.

$51 \quad$ Isnardi Parente and Dorandi (2012), 330.

$5^{2} \quad$ Metaph. I.2, 982b11-21.

53 It is worth noting that if Xenocrates is rejecting the claim that philosophy started with intellectual wonder, he would be disagreeing with Socrates in Plato's Tht. 155d.

54 Clement, Strom. II.5 = Xenocrates F 177 IP $^{2}$. This point is emphasized by Dillon (2003), $150-51$. 
If indeed it is the case that, as scholars since Cherniss have maintained, the activities of the Early Academy can be inferred from the educational programme laid out in Plato's own dialogues, there is a need to consider how its scholarchs Speusippus and Xenocrates, who no doubt continued (in some way) the intellectual practices that were established by their master Plato, reacted to Plato's own commitments to learning, educational practice, and the pursuit of knowledge, as preserved in the dialogues. This essay has only been able to scratch the surface in terms of its approach to educational theory and practice in the Early Academy - to focus primarily on the theoretical and epistemological paradigms advanced by the scholarchs which might have informed their conduct of the "school". Several aspects are prominent: first, it emerges that interpersonal philosophical engagement is thought to be more "conversational" and less adversarial than might have occurred, for instance, in Aristotle's Lyceum. This might be a function of the strong Peripatetic commitments to, and formulation of, endoxastic enquiry and dialectical practice. ${ }^{55}$ Second, the extant evidence shows a focus on the sort of enquiry ( $\zeta \dot{\eta} \tau \eta \sigma \zeta)$ that is directed towards studying the natural world through dichotomous division - a sort of application of the definitional procedures practised by the Eleatic Stranger in Plato's Sophist and Statesman to the topics discussed by Timaeus of Locri in the Timaeus. But grounding this zetetic approach was a positive epistemology ultimately assumed from Socratic debates in the Republic, Meno, and Phaedo: it is as if Socrates was the "mouthpiece" for metaphysics, epistemology, and ethics, whereas the scholarchs turned to the natural illustrations and explanations of the Eleatic Stranger (definitional) and Timaeus of Locri (cosmological) for the procedures and subject areas relevant to education. Interestingly, despite apparent differences in their approaches to the Forms and/or ultimate explanantia, Speusippus and Xenocrates appear to have had compatible approaches to philosophical enquiry and its ends - so far as the evidence suggests, the pursuit and ends of philosophy were apparently the same for both Plato's innovative nephew and his most ardent defender. It is possible, but by no means absolutely certain, that the ideal of "freedom from disturbance" had pre-Platonic roots; ${ }^{56}$

55 One wonders how polyvalent a notion of "dialectic" could have been in Xenocrates' day, when he and Aristotle pursued what appear to be kindred, but not identical, approaches to this issue.

56 Isnardi Parente and Dorandi (2012), 330 associate this ideal with Democritus and Nausiphanes (cf. DK 68 в 4 = DK 75 в 3), but the original source, Clement of Alexandria 
regardless, it was never so effectively integrated into philosophical education until it became philosophy's purpose under the first scholarchs of the Early Academy, Speusippus and Xenocrates. Hence, in their approach to ethics, the first scholarchs both departed from their great master and expressed a view that competed against that of his most famous student.

(Strom. II.130), is not obviously drawing the exact same association. For a valuable attempt to trace out the relationship between Democritus, Nausiphanes, and Epicurus, see Warren (2002), 169-81 (although he does not mention Xenocrates there). 